
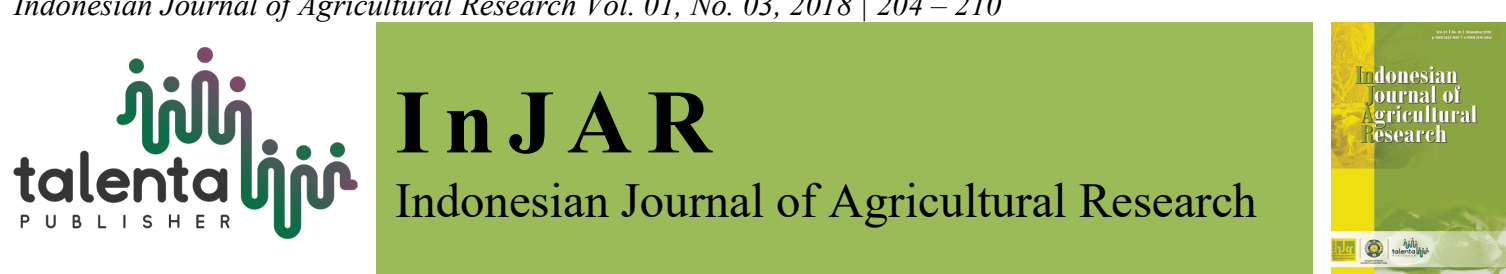

\title{
Prevalence of Helminthiasis in Slaughterhouse Medan
}

\section{Mudhita Zikkrullah Ritonga and Andhika Putra}

University of Pembangunan Panca Budi Medan, Indonesia

\begin{abstract}
Factors affecting the success of the livestock business are feed and disease control. The aim of this study to determine the prevalence of helminthiasis in Slaughterhouse Mabar Medan City. The type of this research is survey research with portrait and analysis of a condition of cattle condition that will be slaughterhoused in Slaughterhouse Mabar Medan City in a certain time. The design of this study is observation or direct observation to the field to see the existing events without intervening from the researcher. The sampling technique is determined by purposive sampling (purposive determination of respondents). Methods of data retrieval is done by observation method that is data retrieval method done by systematically record the result of observation to the events investigated during the research. The result of research in Slaughterhouse Mabar Medan city shows that the prevalence of helminthiasis is $0 \%$. From this result shows the cows that were slaughtered by Slaughterhouse Mabar Medan City is free from the parasitic worm disease.
\end{abstract}

Keywords: helminthiasis, prevalence, slaughterhouse

Received 26 July 2018 | Revised 01 February 2019 | Accepted 04 February 2019

\section{Introduction}

Indonesia is an agrarian country with the livelihood of its people mostly engaged in the agricultural sector. Increasing the number of people followed by increased income per capita makes people increasingly increasing consumption of animal protein. This makes a shift in the diet of people from consuming carbohydrates to animal protein such as meat, eggs and milk.

Beef cattle is one source of meat producers that have high economic value and have significance for the life of the community. A cattle can produce a variety of products, especially meat, and by product such as manure, skin, and bone. Meat is very beneficial for the fulfillment of nutrients in the form of animal protein. The availability of meat is inseparable from the ongoing livestock business.

Some factors were affected in livestock business for example feed and disease control. At this time breeders difficult to get quality and affordable feed. This makes the farmers only take

*Corresponding author at: Animal Husbandry Study Program, Faculty of Sains and Technologi, Universitas Pembangunan Panca Budi, Jl. Jend. Gatot Subroto KM 4,5, Medan, 20122, Indonesia

E-mail address: mudhitaritongavet@gmail.com 
advantage of field grass that is very low quality so that cattle in these communities are prone to disease. Increased production and reproduction will be optimal, if simultaneously accompanied by adequate feed provision and effective disease control [1]. Intestinal parasitic worm infection will be pathogenic, especially if along with bad feeding conditions [2].

Parasitic disease is still considered trivial by the breeders. Diseases caused by parasites are generally not as fatal as deaths to livestock, but cause major losses such as slowing of body weight gain and decreased productivity of livestock. The cause of worm disease is caused by a worm parasite. As a result of parasitic worm infection is very large because the parasite worms absorb the nutrients from the body of the livestock. Parasitic worms also cause the intestinal epithelial cells to be damaged, thus decreasing the function of the intestines in processing food substances.

The control of worm disease in livestock is commonly carried out by using worm medicines, such as benzimidazole, levamisol, and ivermectin [3]. Some cognitive prevention and control measures for cattle in general according to [4] by reducing the source of infection by therapeutic measures, water sanitation supervision, food, shelter and waste conditions and the eradication of intermediate hosts and vectors. In addition to taking precautions, treatment is also done in further tackling the parasitic worm infection [5].

Modern or traditionally maintained farms cannot be separated from obstacles and obstacles including parasitic worm diseases such as Nematodes, Trematodes and Cestodes [6]. Livestock diseases caused by worm parasites can cost the livestock economically as it decreases the yield of the livestock. The results of observation on 96 samples of cow feces, obtained worm eggs derived from two groups of parasitic worms class are Nematode and Trematode [7]. Taenia saginata also founds eggs on the type of Balinese Cattle in the liver and diaphragm [8]. A study conducted at Makassar Animal Slaughterhouse (RPH) showed a high rate of liverworm infection [9]. Infections occurred in 41 head of cattle (53.95\%) of the 76 fecal samples examined. Based on the results of existing studies, it shows that many cows in slaughterhouse have been infected with parasitic worms.

Based on the result of this research, it is necessary to research about parasite worm in cattle in Slaughterhouse Mabar Medan City. Research on epidemiological and internal veterinary parasite studies based on examination of feces and liver in cattle that were slaughtered in Slaughterhouse Mabar Medan City was first performed. Epidemiological studies of calculating the prevalence of parasites of the gastrointestinal worms and veterinary economic studies by calculating the economic losses in the liver infected with the fasciola worms. There have been previous studies in Slaughterhouse Mabar Medan City by [1] but only on the limits of fasciola worm analysis by examining liver and cow feces. 


\section{Materials and Methods}

Methods of data retrieval is done by observation method that is data retrieval method done by systematically record the result of observation to the events investigated during the research [10]. The data retrieval procedure used in this research are: 1) Observation technique that is a method used to obtain primary data; 2) Laboratory examination, that is by identifying the type of worm eggs found in the feces of beef cattle. 3) Document study, ie data collection conducted by viewing, recording and documenting records relating to research as supporting data.

The examination of cow feces are three methods, namely native method, flotation method and sedimentation method. Procedure of native method that is feces sample taken a little and placed on top of glass object, then dropped water and covered with cover glass. Then observed under a microscope with 10x10 magnification and drawing the worm eggs observed. If identification of worm eggs has difficulty, enlargement of the microscope can be increased to 10x40 or 400 times magnification [11].

The method of flotation method is by sampling the feces taken slightly and put in mortar and adding a little water, then stirred with paste until dissolved evenly. Then the mixture of feces was poured into centrifuge tube until $3 / 4$ tube then rotate with centrifuge for 5 minutes. And then pour clear liquid over the precipitate. Pour saturated $\mathrm{NaCl}$ over the precipitate until $3 / 4$ tube and stir until mixed evenly. Then turn again with centrifuge for 5 minutes then put the tube on the rack, position perpendicular. Then drop the saturated $\mathrm{NaCl}$ over the liquid in the tube until the surface of the convex centrifuge tube and leave for 3 minutes. Paste the glass cover on the convex surface carefully, then then quickly cover the glass reversed and placed on the glass object. By examining under a microscope, with magnification 10x10 [12]. If identification of worm eggs has difficulty, microscope enlargement can be increased to 10x40 or 400 times magnification.

Sedimentation method is used for the parasitic worm egg species that settles with the feces. Samples of cow feces taken as much as 3 grams were put in a reaction tube filled with $30 \mathrm{ml}$ distilled stirred until homogeneous. The filtrate is filtered twice using a gauze and cotton cloth into a centrifuge tube. Filtrate is centrifuged for three minutes at a speed of $3000 \mathrm{rpm}$. Then the formed supernatant is dumped slowly leaving a precipitate. The precipitate was given methylene blue and dripped onto a glass object and covered with a glass cover and the precipitate was observed under a microscope [13].

The research parameters observed in this research is worm egg morphology that includes the size and shape of the worm eggs found in the feces of beef cattle. Fieldwork was conducted in Slaughterhouse Mabar Medan and laboratory studies conducted in the laboratory of the University of Pembangunan Panca Budi farm field. The study was conducted from February to March 2017. The type of this research is survey research with portrait and analysis of a 
condition of cattle condition that will be slaughtered in Slaughterhouse Medan City in a certain time. The design of this study is observation or direct observation to the field to see the existing events without intervening from the researcher.

The sampling technique is determined by purposive sampling (purposive determination of respondents). Purposive sampling method selecting a group of subjects was based on the characteristics or specific traits that are considered to have bearing on closely with the characteristics or properties of the population that is already known in advance and selected randomly for sampling carried $10-15 \%$ [14]. Population in this research is all beef cattle slaughtered in Slaughtherhouse Medan City. The sample size was 84 head with the assumption of $30 \%$ fasciolosis and $90 \%$ confidence level. The sample size is calculated using the following formula [15].

The collected research data is processed and analyzed by using descriptive analysis. Descriptive analysis is used to explain the general condition of cattle condition in Slaughterhouse Mabar Medan City. The examination results were analyzed and identified up to the klass level and photomicrographs were made with cybershot cameras to facilitate identification following the way Dewi and Nugraga [16]. The result of the worm eggs obtained is identified by comparing the reference to the literature. The worm eggs that were found were then identified to know its type using Atlas of Parasitology [17] and Atlas Helminthology [18]. All data will then be displayed in the form of images and tables.

The calculation to find the prevalence of gastrointestinal parasite infection using the following formula [19] $\mathrm{F}$ is the number of infected samples and $\mathrm{N}$ is the number of samples examined:

$$
\text { Prevalence }=(\mathrm{F}: \mathrm{N}) \times 100 \%
$$

\section{Results and Discussion}

Results of research conducted in Slaughterhouse Mabar Medan City stated that no parasite worm eggs found in the hundred samples examined. The number of samples examined as many as one hundred samples derived from beef cattle feces that will be slaughtered in Slaughtherhouse Medan City. The samples were all derived from Australian imported cattle with an intensive maintenance model for three months in the area around North Sumatra Province. From the above calculation shows that the prevalence value of helminthiasis in beef cattle slaughtered in Slaughtherhouse Medan City is $0 \%$.

This study was conducted by identifying the existence of parasites of worms in the digestive tract based on the examination of worm eggs in the stool samples. The sample of feces taken from the beef cattle that will be slaughtered at the Slaughterhouse Mabar Medan City. From 
laboratory examination not found any egg worm all samples of feces. This is probably due to all the stool samples taken from imported cattle originating from Australia.

Imported cattle from Australia are fattened cattle for about three months. Fattening is done by large cattle importer companies in North Sumatra. This cattle import company has a model of good and modern maintenance management and health management. This cow importer also has a clean and housing system regularly with administered medication worms during the maintenance process.

This imported cow is maintained intensively in one livestock area. Cows are not removed or grazed during maintenance. Source of water and feed is very payed by the manager so that possibility infected parasite worm very small. Another indication of the absence of worm eggs on feces examination is due to a very good ante-mortem examination by animal health officers in Slaughterhouse Medan. A good examination allows the sick beef cattle to be postponed or rejected for slaughter so that people feel safe to consume meat from Slaughtherhouse Medan. In accordance with the commitment of Slaughterhouse Medan City that provides meat Safe, Healthy, Whole and Halal.

Factors influencing deworming cases in cattle are maintenance method, season and environmental condition and cattle age [20]. Worm infection is also caused by Cestodes besides Nematodes and Trematodes. Infection by Cestode is zoonotic (can attack humans) [21]. Cestode requires two intermediate hosts. The Cestode worms will multiply before infecting the carcivorous animal's intestines, then forming metacestode larvae within the internal organs of the cow and entering the human body.

There are different types of worms and the number of worms in cattle and goats due to some specifications of worm species to certain species of host and topography of livestock. Cows are sensitive to parasitic disease attacks rather than goats or sheep, and cows also have a habit of grazing with their lower lip touching the ground so that worm larvae that by day fall to the grass or soil are consumed by cows [22]. Differences of animal nations also determine whether or not the animal is sensitive to disease attack.

The results of inspection at Samarinda Slaughterhouse in 2009 showed $44.44 \%$ of the 90 samples of cow's feces have been infected Trematode worms [23]. The research results in 2010 [24] on buffalo and cattle found in Slaughterhouse Palembang City showed high intensity of infection came from Trematode class that is Paramphistomum sp.

The Faculty of Mathematics and Natural Sciences of Tanjung Pura University conducted a study in Slaughterhouse Pontianak [6], West Borneo, the results obtained from 80 samples of cow feces examined found seven types of worm eggs, Ascaris sp., Taenia saginata, Trichuris trichiura, Strongyloid sp., Moniezia sp., Fasciola sp. and Paramphistomum sp. The highest 
prevalence of infection is caused by Ascaris sp. (100\%) and lowest Taenia saginata (3.75\%).

The high prevalence is likely to be due to differences in the area of origin of each livestock.

Differences in cow breeding systems such as intensive and extensive maintenance affect the degree of risk of being infected by worm parasites. Extensive maintenance causes cows to easily be infected with worm parasites in grazing areas. Intensive maintenance can reduce the risk of worm parasite infection due to animal feed given in the cage. The control of parasitic worm disease in intensive system maintenance is so important that the cows that are slaughtered in Slaughterhouse Mabar Medan City none of them are infected with parasitic worms. Slaughterhouse Mabar is said to be free from parasitic worm infections due to the majority of beef cattle slaughtered from intensive cattle. The other slaughterhouse described above is highly susceptible to parasitic worms because the cows that are slughterhoused in the slaughterhouse are derived from a local sari with an extensive maintenance system.

\section{Conclusion}

The results showed that the prevalence of helminthiasis in Slaughterhouse Medan City is $0 \%$.

\section{REFERENCES}

[1] I. Ambarisa, I. Marsaulina dan W. Hasan, "Analisis Cacing Hati (Fasciola hepatica) pada Hati dan Feses yang Diambil dari Rumah Potong Hewan di Mabar Medan," Departemen Kesehatan Lingkungan, Fakultas Kesehatan Masyarakat, Universitas Sumatera Utara, Medan, 2013.

[2] S. Koesdarto, S. Subekti, dan H. Studiawan, "Model Pengendalian Siklus Infeksi Toxocariasis dengan Fraksinasi Minyak Atsiri Rimpang Temuireng (Curcuma Aeruginosa Roxb)," Penelitian Mediaeksakta, Madura, 2001.

[3] I. Mustika, dan Z. A. Riza, "Peluang Pemanfaatan Jamur Nematofagus untuk Mengendalikan Nematoda Parasit pada Tanaman dan Ternak," Jurnal Litbang Pertanian, vol. 23, No. 4, pp. 115, 2004.

[4] S. Subekti, S. Mumpuni, S. Koesdarto dan Kusnoto, "Buku Ajar Ilmu Penyakit Helminth Veteriner," Fakultas Kedokteran Hewan, Universitas Airlangga, Surabaya, 2011.

[5] S. Koesdarto, S. Subekti, S. Mumpuni, H. Puspitawati dan Kusnot, "Buku Ajar Ilmu Penyakit Nematoda Veteriner," Fakultas Kedokteran Hewan, Universitas Airlangga, Surabaya, 2007.

[6] Tantri, Novese, Setyawati Tri Rima dan Khotimah Siti, "Prevalensi dan Intensitas Telur Cacing Parasit pada Feses Sapi (Bos Sp.) Rumah Potong Hewan (RPH) Kota Pontianak Kalimantan Barat," Program Studi Biologi, Fakultas MIPA, Universitas Tanjungpura, 2013.

[7] N. Erwin, M. Kamal, dan A. Rusdiana, "Identitas Jenis Telur Cacing Parasit Usus Pada Ternak Sapi (Bos sp.) dan Kerbau (Busbalus sp.) di Rumah Potong Hewan Palembang," Jurnal Penelitian, Universitas Sriwijaya, Palembang, 2010.

[8] Dharmawan, Nyoman S, Damriyasa I Made, Kapti I Nengah, Sutisna Putu, Okamato Monehiro dan Ito Akira, "Experimental infection of Taenia saginata Eggs in Bali Cattle: ditribution and density of Cystercercus bovis," Jurnal Veteriner, vol. 10, no. 04, 2009. 
[9] Purwanta, Ismaya, N. R. P., dan Burhan, "Penyakit Cacing hati (Fascioliasis) pada Sapi Bali di Perusahaan Daerah Rumah Potong hewan (RPH) Kota Makassar," Jurnal Agrisistem, vol. 2, no. 2, 2006.

[10] Marzuki. Metodologi Riset. Yogyakarta: BPFE_UI, 2000.

[11] S. Subekti, S. Mumpuni, S. Koesdarto dan Kusnoto, "Buku Ajar Helminthologi Veteriner,” Fakultas Kedokteran, Hewan Universitas Airlangga, Surabaya, 2010.

[12] B. T. Shaikenov, "Short Report the Use of Polymerase Chain Reaction to Detect Echinococcus granulosus (G1 strain) Eggs in Soil Samples," AM. J. Tropic. 2004.

[13] P. Murray et al., Manual of Clinical Microbiology. 8th ed. Washington DC: American Society for Microbiology, 2003.

[14] D. Kuswana, Metode Penelitian Sosial. Bandung: Pustaka Setia, 2011.

[15] S. Selvin, Statistical Analysis of Epidemiology Data. London (UK): Oxford University Press, 2004.

[16] K. Dewi and R.T. P. Nugraha, "Endoparasit pada feses babi kutil (Sus verrucosus) dan Prevalensinya yang Berada di Kebun Binatang Surabaya," Surabaya, 2007.

[17] J. Prianto, T. P. Utama and Darwanto, Atlas Parasitologi Kedokteran. Jakarta: Gramedia, 2010.

[18] J. Purnomo, Gunawan, Magdalena, Ayda, and Harijani, Atlas Helminthologi Kedokteran. Jakarta: Gramedia Pustaka Utama, 2008.

[19] S. Budiharta, "Kapita selekta epidemiologi veteriner," Fakultas Kedokteran Hewan. Universitas Gadjah Mada, Yogyakarta, 2002.

[20] Medion, "Cacingan pada sapi jangan dianggap enteng," 2013.

[21] Tarmudji, "Eknokosis/Hidatidosis Suatu Zoonosis Parasit Cestoda Penting terhadap Kesehatan Masyarakat," Balai Besar Veteriner, Lokakarya Nasional Penyakit Zoonosis, Bogor, 2006.

[22] H. Blakeley and G. Bade, “Anatomi comparative,” London: Logman Group, 1984.

[23] Jusmaldi and Y. Saputra, "Prevalensi infeksi cacing hati (fasciola hepatica) pada sapi potong di Rumah Potong Hewan Samarinda," Jurusan Biologi FMIPA Universitas Mulawarman, Bioprospek, vol. 6, no. 2, 2009.

[24] N. Erwin, M. Kamal, and A. Rusdiana, "Identitas Jenis Telur Cacing Parasit Usus Pada Ternak Sapi (Bos sp.) dan Kerbau (Busbalus sp.) di Rumah Potong Hewan Palembang," Jurnal Penelitian, Palembang, 2010. 